\title{
Worship: bowing down in the service of God
}

\author{
Avital Hazony Levi \\ Department of Philosophy, University of Arizona, Tucson, Arizona 85721, USA \\ email: ahazony@email.arizona.edu
}

(Received 31 December 2019; revised 30 January 2021; accepted 1 February 2021)

\begin{abstract}
Philosophers commonly assume that worship is a universal attitude. Two major approaches see worship as a sui generis attitude or as the specific attitude of respect. This article criticizes the universal assumption and defines worship as a ritual that shapes a person in acquiring the attitude considered appropriate in relating to a superior such as God. Religions differ in their rituals of worship because they disagree on what this appropriate attitude is. This claim is demonstrated by distinguishing the Hebrew Bible's form of worship as bowing down. Biblical worship is shown to be political, forming the worshipper into a loyal servant of God as king. This form of worship is argued to be fundamentally ethical because it teaches that the individual's relationship with God supervenes on human relationships.
\end{abstract}

Keywords: worship; Hebrew Bible; ritual; bowing down

\section{Introduction}

In this article I develop and defend the conception of worship found in the Hebrew Bible. The article has two motivations. First, the philosophical discussion of worship has tended to offer an analysis which is meant to apply universally, across religions. I think this is a mistake. Religions vary greatly in their conceptions of God, of man, and of the relationship between the two. By trying to define a universal archetype of worship, philosophers unwittingly overlook notions of worship that are different from their own. Instead I suggest a thin concept of worship: those rituals that shape the appropriate attitude to God according to a particular tradition. On this view, in order to understand worship we must delve into a particular tradition.

Second, the philosophical discussion of worship has mostly focused on an individual's attitude or emotion, thereby portraying worship as part of a one-on-one relationship between man and God that transcends a person's other human relationships. In contrast, the Hebrew Bible's notion of worship as bowing down, kneeling, or prostrating oneself in service of God shapes a person to carry out God's will of bringing justice and charity to human relations. By elucidating the notion of worship that is particular to the Hebrew Bible, I hope to offer a compelling view of worship, thereby bringing clarity to those who view the Hebrew Bible as authoritative and challenging competing views of worship to explain the relation between worship and ethics.

In the first three sections of the article I critique the existing theories of worship. I argue that stipulating that worship is a sui generis attitude renders worship unintelligible,

(c) The Author(s), 2021. Published by Cambridge University Press. This is an Open Access article, distributed under the terms of the Creative Commons Attribution licence (http://creativecommons.org/licenses/by/4.0/), which permits unrestricted re-use, distribution, and reproduction in any medium, provided the original work is properly cited. 
while defining worship as a particular attitude fails to encompass the varied forms of worship. I therefore define worship as the ritual that forms the basic attitude considered appropriate between human beings and God who is superior to them. In the next two sections I analyse biblical terms and passages to show that in the Hebrew Bible worship refers to the act of bowing down (hishtachava), which is part of the service (avoda) of a servant. I argue that 'worship' is a term taken from the political realm of masters and servants because, like human kings, God needs servants who will accept his rule and utilize their knowledge, power, and initiative in achieving his goals. ${ }^{1}$ In the final two sections I argue for the ethical significance of the biblical form of worship. I respond to the view that bowing down is demeaning and argue that the metaphor of God as king teaches that our relationship to God is shaped by our relationship to his other subjects, and thus that the biblical view of worship is fundamentally ethical.

\section{Epistemological difficulties facing the sui generis criterion for worship}

Important articles in the study of worship have held that worship is a sui generis attitude, unlike any other. ${ }^{2}$ The conclusion of many of these arguments has been that worship of God is not possible, and that God as the one addressed in worship cannot exist. I will argue that the epistemic problems that lead to these conclusions are not problems with worship itself, but rather with the sui generis criterion, which undermines the epistemic pathways to understanding worship.

Tim Bayne and Yujin Nagasawa present a recent example of the view that worship is sui generis, unlike any other attitude. They argue that there are no epistemologically defensible grounds for worship by considering three possible grounds: God's creation of the world, God's maximal goodness, and the prudence of worship. They demonstrate that none of these grounds give sufficient reason to have an attitude towards God that is unlike any other. I suggest that they find these characteristics lacking as grounds because they are looking for grounds for a sui generis attitude. Let's take a look at one of their arguments to show this.

When considering whether God's creation of the world is a reason for worship, Bayne and Nagasawa argue that such grounds would reduce worship to gratitude, "thereby emptying it of its moral, aesthetic, and noumenal components' (Bayne and Nagasawa (2006), 306). Of course, gratitude has moral and aesthetic components. What Bayne and Nagasawa mean is that by likening worship to gratitude we empty worship of its content that is unlike any other attitude. If we point to creation as grounds for worship, we will think of worship as something like gratitude, which is an appropriate response to creation. But this will lead us to reduce worship to gratitude rather than to understand the grounds for a sui generis attitude. Bayne and Nagasawa conclude that taking any characteristic of God as grounds for worship will lead us to consider what other, familiar attitude is an appropriate response to this characteristic, thereby leading to a reduction of worship to that attitude.

Bayne and Nagasawa are right to raise these epistemic difficulties, but they draw the wrong conclusion. The problem is not with worship, but with the attempt to make worship into something sui generis. Creation of the world or maximal excellence do ground attitudes, such as gratitude or awe, but we cannot see how they could ground an attitude that is unlike any other. This is because it is impossible for us to understand what could ground an attitude unlike any other. Any grounds suggested will be dismissed because of our own epistemological tendency to compare to that which is familiar to us. ${ }^{3}$ We are not able to understand without comparisons, and thus our own human understanding cannot conceive of grounds for a sui generis attitude.

The problems caused by the sui generis criterion are not limited to grounding worship. This criterion cuts off the epistemic pathways that enable us to understand what worship 
actually is. Hugh Burling argues that proponents of the sui generis conception of worship are at a disadvantage of identifying the 'moral, aesthetic and noumenal components' of worship. This is because 'any account [of worship] must draw parallels with inter-creature phenomenology in order to make clear how it secures these components' (Burling (2019), 492). In order for human beings to understand what worship is, they must draw on comparisons to their other, more familiar, relationships.

One could argue that the criterion of sui generis is not meant to explain what worship is. On this view, the phenomenology of worship will point to what worship is, while the formal criteria will only tell us when we are wrong to think that something is worship. ${ }^{4}$ But this reading will not do, since the sui generis criterion also prevents us from recognizing worship when we see it. If you believe that worship is a sui generis attitude, then any attitude that is even a little like another attitude you have experienced will be deemed an unworthy candidate of worship. Now, it is likely that any attitude we in fact have towards God - gratitude, reverence, awe, fear, love - will be like the attitudes we have towards human beings. But as soon as this similarity is detected, we will be forced to deem our attitudes towards God not worship, not because of any lack we find in our attitude but because it doesn't meet the sui generis criterion. ${ }^{5}$

This wild goose chase that the sui generis criterion sends us on is reflected in the philosophical literature on sui generis worship. Bayne and Nagasawa themselves offer an analysis of worship as a cluster concept of beliefs, such as the belief that God is morally superior and more powerful, and attitudes such as fear, awe, admiration, veneration and love. ${ }^{6}$ Although Bayne and Nagasawa contend that philosophers need to engage in a serious discussion regarding the concept of worship, most philosophers who respond to Bayne and Nagasawa's argument focus on the obligation to worship without offering a detailed theory of worship itself. Jeremy Gwiazda and John Danaher argue about the obligation to worship, without offering any definition of worship. ${ }^{7}$ Benjamin Crowe mentions, but does not commit, to worship being an activity that expresses love, fear, and service. However, he later (quoting Aquinas) seems to revert to a sui generis view of worship. ${ }^{8}$ This vagueness in the literature is not surprising. Positing the sui generis criterion of worship forces us to pay lip service to an unknown attitude while robbing us of any ability to describe what it actually is. We are left with arguments concerning the possibility of worship or the obligation to worship, with no clear debate on the nature of worship itself.

\section{Overcoming the uniqueness of worship}

Understanding worship as sui generis causes epistemic difficulties. I argued that this is because positing that worship is sui generis cuts the analysis of worship off from comparisons to human relationships that give it content. But why do philosophers stick to this criterion, if it is so problematic?

Underlying the sui generis criterion is the intuition that because monotheism posits one God, it requires that we relate to God with an attitude unlike any other. Bayne and Nagasawa suggest that what differentiates monotheists from polytheists is the uniqueness thesis, that God alone is the appropriate addressee of worship. ${ }^{9}$ The evidence they bring for this is a reference to Exodus 20:4, where God prohibits the worship of other gods. ${ }^{10}$ They then attribute to all monotheists the view that the belief in one God necessitates that there be only one appropriate addressee of worship, and thus that worship must be a sui generis attitude. ${ }^{11}$

But monotheism does not necessitate the view that God alone is to be worshipped. In the Hebrew Bible God prohibits the worship of other gods, but there is no similar prohibition to worship human beings. This may be surprising, but it makes sense in light of the 
fact that any term that describes the relationship between God and man in the Hebrew Bible also characterizes human relationships. ${ }^{12}$

Continuity between terms referring to religious and human affairs is characteristic of biblical Hebrew. ${ }^{13}$ In The Philosophy of Hebrew Scripture, Yoram Hazony explains that when the prophets utilize terms such as king, father, rock, and many other terms to describe God, they utilize concepts used in their daily lives, and recognizable from human experience, to teach about God. The combination of these metaphors, and their interchangeable use, teaches that none of them is sufficient to describe God. Each metaphor describes an aspect of God, so it is only by combining the metaphors that we can begin to fathom what God is like. ${ }^{14}$

We can use Hazony's model in our present discussion of the Hebrew Bible's view of worship. Just as we cannot know God without referencing human experience, we also cannot learn how to relate to God without reference to human relationships. This explains why in the Hebrew Bible all verbs that direct us in our relationship with God are taken from the realm of human experience and especially from human relationships. For example, if we want to understand the commandment to cleave (davak) to God (Deuteronomy 11:22) we can look to its use in describing the relationship between husband and wife (Genesis 2:34) or Ruth's loyalty to Naomi (Ruth 1:14). The Hebrew Bible thus avoids the epistemic difficulties caused by the sui generis criterion, by commanding we shape our relationship to God by taking up attitudes familiar from human relationships. This is not because God is just like a king or a father but because the way we relate to a king or a father are referents that teach us how to relate to God.

Philosophers have assumed that the Hebrew Bible, too, has a sui generis conception of worship. This is because translators projected their own view of a sui generis worship into their translations, by reserving the term 'worship' for the relationship with God. The King James Bible uses 'worship' to translate the ritualized action of bowing down (hishtachava). ${ }^{15}$ But the KJB only uses 'worship' when the text is referring to bowing before God, and uses 'bow' to translate the very same Hebrew term when referring to bowing before a human being. This translation is misleading. The Hebrew Bible uses the same term for bowing before God and bowing before kings and other powerful individuals (see, for example, Genesis 33:3). Thus worship on the biblical view is not a unique phenomenon that occurs between humans and God. ${ }^{16}$

Since the language of the Hebrew Bible doesn't seem to support a sui generis view of worship, and the Hebrew Bible is one of the major (if not the first) proponents of monotheism, it must be that believing in one God does not necessitate that one have an attitude towards God that is unlike any other. ${ }^{17}$ The singularity of God can be understood to mean that he is the ultimate addressee of a certain attitude, rather than the only addressee of that attitude. ${ }^{18}$ God being the ultimate, rather than the only, addressee of worship requires that the worship of humans be limited by the worship of God. For instance, if worship were to require obedience or love, then a worshipper would obey or love only those human beings who made it possible for him to obey or love God, and would not obey or love those human beings who made it impossible to obey or love God. Such limitations on our attitudes do not require that the attitude directed towards God be unlike any other, but rather that we give more weight to that attitude when it is directed towards God. $^{19}$

I will develop the biblical notion of worship, and explain its grounds, in greater detail below. What is important to stress here is that the monotheist view of the Hebrew Bible does not require that God be the only addressee of worship. God is unique because He is the ultimate addressee of worship. This allows for God to merit worship on the very same grounds as human beings merit worship. What makes the grounds for worship intelligible is precisely the fact that God merits worship in the same way that human beings merit it. 


\section{Changing the conversation}

We have seen that the sui generis criterion of worship does not lead to an understanding of worship, nor is it required on a monotheistic theology. The only major approach to worship developed in response to Bayne and Nagasawa's challenge is offered by Hugh Burling, who follows Richard Swinburne in understanding worship to be an attitude familiar from human relationships. I wholeheartedly agree with Burling's criticism of the sui generis view, discussed above. In this section I consider his methodology and his substantive suggestion that worship is a kind of respect. I argue that the attempt to define worship as a particular attitude fails. In light of Catherine Bell's claim that rituals form, rather than express, attitudes and beliefs, I argue that it is unlikely that the varied worship rituals across religions form a single attitude. I conclude that worship is not defined by a particular attitude, but rather by its role in shaping the appropriate attitude considered fundamental to the hierarchical relationship between man and God.

Burling is the only one in recent literature to respond boldly to Bayne and Nagasawa's charge that philosophers have not offered an analysis of worship. Burling draws on Swinburne's view that worship is 'to show explicit respect towards a being acknowledged as the de facto and de iure lord of all things' ${ }^{20}$ Burling develops this view, suggesting that worship is an attitude on the continuum of respect. He suggests that since we have different degrees of respect for people depending on their excellence (varying from politeness, to friendship, to admiration, to veneration), worship is the special kind of respect we have towards the maximally excellent. This unique attitude, ${ }^{21}$ Burling suggests, will include 'reactive attitudes to perfection, such as admiration or awe' (Burling (2019), 494).

Burling and Swinburne are importantly aware that any definition of worship must encompass a great variety of rituals, and that this creates a problem for their view that attempts to define worship with a single attitude. Their solution is to suggest that worship is an attitude that is flexible enough to explain this variability. Respect, they contend, takes different forms depending on culture and context. On their view, then, the attitude of worship, a particular kind of respect, is common to all religions, but the way it is expressed differs from one tradition to another. ${ }^{22}$

There are two problems with this suggestion. First, the attitude of respect, for all its flexibility, cannot encompass all forms of worship. Let us first take some extreme examples. The Mishnah reports that the god of Pe'or was worshipped by defecation. ${ }^{23}$ Graeco-Roman Bacchanalian gods were worshipped with drunkenness, lewdness, and licentiousness. Whatever attitude these forms of worship might have expressed, it is unlikely that they expressed respect. Swinburne is aware of this complication, and therefore limits his analysis of worship to monotheist traditions. ${ }^{24}$ This limitation indicates that Burling and Swinburne are not offering an analysis of worship but of a particular kind of worship.

The particularity of worship as respect is underscored, when we notice that it doesn't include the Hebrew Bible's form of worship. According to Swinburne and Burling's explanation, respect is an acknowledgement of the worth of the object of respect. This means that respect is an impersonal attitude, which does not reference the importance of the object of respect to the person paying the respect. As mentioned above, Burling emphasizes that respect varies with the excellence of the object of worship, and Swinburne's explication makes it clear that respect can be shown to a stranger with whom the one paying the respect has no further relationship. ${ }^{25}$ In contrast, the form of worship that the Hebrew Bible commands is personal. As shall be discussed in greater detail below, biblical worship shapes the worshipper into a servant of God, and so it revolves around the importance of God to the worshipper. Although on the face of it there is commonality between Swinburne's view of God as ruler and the Hebrew Bible's 
view of God as king, there is deep disagreement regarding the meaning of worship. For Swinburne and Burling, worship is an acknowledgement of God's greatness, a greatness that is not dependent on the worshipper in any way. For the Hebrew Bible, worship is the forming of oneself into a servant who participates in and strengthens God's sovereignty.

Thus the first problem with Swinburne and Burling's account of worship as respect is that it doesn't allow for sufficient disagreement. It is not the case that different forms of worship are different expressions of the very same common attitude of worship. Rather different forms of worship indicate that different religions, and even different monotheistic traditions, disagree on the attitude that is fundamental to the relationship between man and God.

The second problem with Swinburne and Burling's view is that they equate worship with an attitude, rather than with the rituals that bring about that attitude. Swinburne says that 'To offer to a being worship ... is surely to show explicit respect' (Swinburne (1993), 293), and repeatedly uses the term 'acknowledge' in his account of worship. Burling says that 'Some actions might be obligatory insofar as they are ordinary manifestations of obligatory attitudes' (Burling (2019), 494), clearly taking actions to be an expression of an attitude. ${ }^{26}$ But equating worship with an attitude does not reflect the common use of the term 'worship' in referring to ritualized actions themselves. The rituals of prayer, bowing down, burning incense, bringing sacrifices, or singing praise are all referred to as worship. These philosophers seem to regard these actions as expressions of an attitude of worship.

A theory of ritual as an expression of worship is developed by Ninian Smart. Smart argues that the act of ritual, in itself, cannot be worship, since we can perform the same actions with differing intentions and attitudes. He therefore concludes that worship is a set of specific beliefs and attitudes expressed in action. For example, he says that 'Bowing down is more than a physical movement ... the use of this bodily movement to express worship involves more than a physical movement' (Smart (1972), 6-7, emphasis added). ${ }^{27}$ Smart defines worship as instances of ritual which express the superiority of the one addressed and the awe of the addresser. ${ }^{28}$ Smart therefore concludes that only ritual performed as an expression of awe at the superiority of the addressed is worship.

The problem with such a view of ritual is that it overlooks the active role of ritual. ${ }^{29}$ Ritual theorist Catherine Bell has challenged the view of ritual as an expression of an internal state. She argues that such a view wrongly distinguishes between belief and physical movement, and rests on a false dichotomy between thought and action. ${ }^{30}$ she shows that ritual has an active role in forming the agent and the social structures of which the agent is a part. ${ }^{31}$ Moreover, Bell argues that a person performing a ritualized act learns new categories of knowledge by shaping herself and the social structures of which she is a part. $^{32}$ Bell's work shows that ritual does not express an attitude or belief that the agent already has but rather shapes her attitudes and beliefs. ${ }^{33}$ We cannot understand worship as an expression of some attitude, if the role of worship is to produce the attitude. Smart's concern, that instances of ritual may be carried out with various intentions, loses its force on the view that repeated ritual will eventually bring about the appropriate attitude.

This criticism of Bell's points to the second problem with Swinburne and Burling's attempt to define all worship, or at least all monotheistic worship, as expressing one attitude. Bell's argument that rituals shape the worshipper's role, attitudes, and beliefs suggests that different rituals shape different roles, different attitudes, and different beliefs. The worshipper who bows will not come to have the same attitude as the worshipper who sings praise because different repeated actions are designed to achieve different ends. Based on Bell's understanding of the effects of ritual, the view that varied forms of 
worship can be found to express a single attitude of respect is quite unlikely. It would require that very different rituals will miraculously shape the same attitude, when in fact rituals are carefully developed to have particular effects.

These two points - that religions disagree on the attitudes most salient to worship, and that rituals do not primarily express but shape us to adopt these attitudes - lead me to offer a new definition of worship. The concept of worship will be quite thin, not offering a full understanding of worship but rather pointing to what is common to different forms of worship and where they coherently disagree. Worship is a ritual that forms the agent's attitudes and beliefs considered appropriate in a hierarchical relationship between the agent and one far greater than the agent (in some cases, God). ${ }^{34}$ Thus, worship is directed to one who is far greater than the one worshipping. ${ }^{35}$ It is part of a hierarchical relationship and its role is to shape the worshipper in acquiring the attitude most appropriately directed towards the one worshipped.

Such a thin analysis has some content, since it tells us that God is superior to the worshipper and that worship is a ritual that shapes the worshipper's attitude towards God. Such a thin concept does not specify grounds for worship (God or another addressee of worship could be great in different ways) nor does it specify the attitude worship shapes in response to these grounds. These are precisely the areas of disagreement among traditions that give rise to competing forms of worship. Different traditions have different forms of worship to form different attitudes, depending on these traditions' views of the nature of God, the nature of man, and the appropriate relationship between them. Thus a religion that emphasizes God's maximal excellence will practice forms of worship that inculcate admiration, whereas a religion that focuses on God's just sovereignty will practice forms of worship that cause the worshipper to take up an attitude of service. This is why only contextualizing forms of worship will allow us to grasp the intelligibility of the reasons to worship, overcoming the grounding difficulties raised by Bayne and Nagasawa. $^{36}$

This analysis of worship is not empty, like the sui generis criterion, but it doesn't offer us a full account of worship as the respect view of worship did. What my analysis offers is a concept that includes and renders intelligible different forms of worship. It also allows us to compare forms of worship for their strengths and weaknesses. In order to give a thick concept of worship, on my analysis, we will need to delve into a particular tradition and articulate the notion of worship it teaches by analysing key rituals it prescribes and observing what attitudes they bring about. In the remainder of this article I will demonstrate how such a full notion of worship can be developed by investigating worship as prescribed in the Hebrew Bible. I turn to this tradition because it offers a challenging and illuminating alternative to the views of worship we have seen thus far.

\section{Worship as bowing down}

The King James Bible translates bowing before God as worship. Although this ritual is not the only form of worship we find in the Hebrew Bible, I agree with the KJB translators that it is most fundamental to forming the relationship the Hebrew Bible teaches is appropriate between man and God as king. ${ }^{37}$ In this section I analyse the ritual of bowing itself, and in the next section I draw on biblical passages to describe the political hierarchy that bowing down forms between God and man.

Biblical scholar Dru Johnson applies Bell's theory of ritual to the biblical text, and shows that in the Hebrew Bible rituals instructed by God are understood to impart knowledge. ${ }^{38}$ As philosophers working in extended cognition and phenomenology have argued, knowledge is not gained independently of the body, but rather through the body. ${ }^{39}$ Bodily actions that are ritualized - particularly ones that involve habituation, increasing 
sensitivity, and progression - bring the person performing the ritual to acquire knowledge that they could not have known otherwise. ${ }^{40}$ Thus when we come to discuss bowing down, we need to discuss both what attitude is formed by bowing and what knowledge is gained through it.

Bell and Johnson caution that the epistemic role of ritual means that we cannot grasp categories of knowledge known by ritual without performing the relevant action in its appropriate context. This means that describing the knowledge gained through bowing, without actively bowing ourselves, doesn't allow us to access the knowledge gained by bowing. But I think it is important to try to give some indication of the knowledge that is gained through action. Following Bell, I will argue that bowing shapes a person into a servant. Following Johnson, I will claim that bowing in service brings the worshipper to discern God as king. How exactly does bowing do this?

When we bow down, we cover our eyes, which we use to perceive danger and understand our surroundings. This brings us to discern and focus on the limits of our power and understanding and become aware of our need for rule and assistance. ${ }^{41}$ We place ourselves in a position that lowers us before someone else, and makes us vulnerable to them by exposing our backs and limiting use of our arms and legs. By covering our eyes and taking our focus off what we see and understand, we open ourselves to hear the voice of someone else, thereby receiving the guidance and rule of someone more powerful, just, and wise than us. ${ }^{42}$

While bowing reveals our limitations, it also places us in a position to be surveyed by our superior. When we place ourselves to be surveyed by our superior, we are not merely seen for our weaknesses but also for our strengths. Rachels points out that bowing before a monarch meant acceptance of one's role - one's responsibilities and benefits. ${ }^{43}$ Our initiative in bowing commits whatever power and knowledge we do have to the service of a superior. In bowing before someone we develop our loyalty by refraining from threatening our superior and taking initiative to act upon his will.

Bowing is not an expression of an attitude that maintains the status quo of a relationship, as Smart suggests. ${ }^{44}$ When we bow we shape the hierarchical relationship. We make someone else more powerful by allowing him or her to take charge and direct us, and we make ourselves less powerful before the one we turn into our superior. As Bell puts it, 'required subordination does not merely communicate subordination to the kneeler ... kneeling produces a subordinate kneeler in and through the act itself (Bell (2009), 100). The act of placing oneself before God forms one's own expectations as well as the expectations of God and of those who witness the action. It thereby greatly raises the pressure of living up to the service one initiated with the bow. In this way it teaches us the meaning of God as king, when we open ourselves to God's commands and habituate ourselves to act upon his will.

Thus bowing or kneeling is not an expression but a ritualized act that shapes the servant-master relationship between man and God. Bowing down initiates and then strengthens a relationship characterized by service. In bowing a person invites God to take charge and govern faithfully, and initiates carrying out the will of God when and where he thinks it necessary. Unlike Swinburne's view that worship is an expression of respect for God's rule, the biblical view is that we bow down to become ourselves servants of God who participate in making God our king.

\section{The political relationship between God and man}

Why does the Hebrew Bible command bowing ourselves as a key form of worship? In this section I contend that this form of worship fashions a political relationship between God and man. The attitude of service acquired by the worshipper enables him to assist God in 
his political aims. Man's service includes, but cannot be reduced to, obedience or emotion, because according to the Hebrew Bible God most fundamentally seeks assistance in bringing about peace and justice.

Rachels points out that bowing before someone is 'not ... an isolated act' but rather part of 'a role which dominates one's whole way of life'. ${ }^{45}$ This means that someone who bows before God doesn't merely admire or respect the greatness of God in a particular instance, but rather takes on the role of the servant of God in all aspects of life. This is why the biblical commandment to bow often comes in conjunction with the commandment to serve (evod) (see, for example, Genesis 27:29; Exodus 20:4; Deuteronomy 5:8; Deuteronomy 11:16). Loyal service is the more general attitude that is acquired through worship on the biblical view, and this service, I will show, is a political one.

What does the commandment to serve God mean? When reading Exodus in Hebrew, one finds that God promises to take the Israelites out of servitude (beit avadim) (Exodus 20:2), and remove them from the terrible service they must perform for Pharaoh (avodat parech) (Exodus 1:14). This freeing of the Israelite slaves seems to imply that God condemns service. Yet God sends Moses to free the Israelites in order that they will serve God (va'avavduni) in the desert (Exodus 7:16). It turns out that when the Israelites are freed from slavery, they are not freed in order to stop serving. Rather, they are offered the exchange of a tyrannical master for a redeeming master and are asked to choose. According to the Hebrew Bible, some forms of service are slavery, whereas some forms of service are good. ${ }^{46}$

Modern Western societies prize equality, so it is hard for those living in them to imagine what would be good about being a servant, someone who is subservient to a master. In order to understand the Hebrew Bible's view on this issue, let us think of the world of kings that was the political reality of the biblical cultural context. A king can only defend his kingdom from external enemies, ensure peace from internal turmoil, and enable the religious, cultural, and economic prosperity of his people if he has loyal individuals who strengthen his rule. He cannot carry out or even oversee all the many projects that are required for prosperity, so he needs people who will assist him. These loyal individuals carry out the king's decrees and warn him of those who wish to undermine him. Such individuals are valued because many human beings who have influence and power tend to utilize them to undermine the king and strengthen their own rule. A country filled with such people will fall into turmoil and bloodshed. A king who rules such people will not remain king for long. Thus, servants who serve the king make his rule possible. Kingship, with the order, peace, and prosperity it brings, ${ }^{47}$ is dependent on the loyalty of the king's servants. Service is good because it makes order, peace, and prosperity possible.

The Hebrew Bible likens God to a king (see for example Exodus 16:18; Judges 8:23; Samuel I 8:7), a king who wants peace and justice for his people. This comparison teaches that God, too, needs the assistance of human beings to ensure the stability of his rule. God needs servants who do not seek ultimate rule but rather seek to assist in strengthening God's rule. Like a human king, God cannot carry out his plans to bring about peace and justice on his own. He oversees the actions of others, but he needs human beings who will take charge, command, lead, and act as an example so that his peace and justice will prevail. This is why we find that the individuals who are called servants of God in the Hebrew Bible are those who use their position, power, and influence to strengthen God's rule. ${ }^{48}$ For example, God chooses his servant Abraham to found the Israelite people because he knows Abraham will teach his children God's way of doing justice (Genesis 18:19). We can conclude that the commandment to serve God is not a commandment to be a slave. It is instead a commandment to use one's power and influence to serve God by keeping his laws and carrying out his will. ${ }^{49}$ 
The attitude of service acquired by biblical worship cannot be reduced to obedience. ${ }^{50}$ It is true that the Hebrew Bible commands the Israelites to carry out God's commandments, giving detailed instructions to be obeyed in all aspects of life. The loyal person carries out the will of his master, which requires obedience to these commands. But loyalty cannot be reduced to obedience: since the master cannot oversee every situation, the loyal person must sometimes act in situations where there are no clear commands from his master. Loyalty requires initiative and wisdom. Consider, for example, Abrahams's servant, who is sent to find a wife for Isaac, and is left to his own devices and discretion with regard to choosing a wife and convincing her to follow him (Genesis 24). The loyal person not only obeys commands but carries out what he knows is God's will.

Just as service cannot be reduced to obedience, it also cannot be reduced to performing rituals. Rituals are prescribed clearly and require precise following. ${ }^{51}$ The rituals of the Temple are called 'service' (avoda), so clearly ritual is part of the service of God. But performing ritual, on its own, does not turn one into a servant. This is emphasized by the prophets of Israel who chastise those who perform rituals but act unjustly towards human beings. ${ }^{52}$ Ritual is meant to bring about an attitude that is carried into the rest of one's life. God who seeks justice is not satisfied with the ritual itself but rather expects it to motivate action in the political and social realm.

The upshot of this analysis of service is that a form of worship that aims to shape its observers into servants cannot be reduced to an attitude. Bowing down inculcates an attitude of loyal service, but the attitude of loyalty is not primarily an internal state. It is a way of acting that achieves certain ends in the social-political realm. ${ }^{53}$ Although being a servant is enabled by certain emotions, and the Hebrew Bible commands love and awe of God that motivate service, ${ }^{54}$ these emotions are only worthwhile as part of a life of service. The loyal servant is not primarily focused on achieving an emotional state but on bringing about God's rule.

Specific emotions, obedience, and performing ritual are necessary in our service of God. But the fundamental relationship taught by the Hebrew Bible is one of service to God's will and plan. In order to succeed in serving God a person must take initiative and act effectively. This is because the God of Israel is not primarily looking for blind obedience, an emotional connection, or the performance of ritual. The Hebrew Bible teaches that God is looking to bring justice into the world, and therefore He most values those servants who share this political goal and assist Him in achieving it through political action. ${ }^{55}$

\section{Is bowing down unethical?}

Those who object to worship consider bowing oneself unethical. Findlay and Rachels understand bowing to be a surrender of judgement since, as Rachels puts it, worship requires complete subservience: 'in admitting that a being is worthy of worship we would be recognising him as having an unqualified claim on our obedience' (Rachels (1971), 334). Findlay puts bending one's knee in the same category as deferring wholly, devoting oneself with unquestioning enthusiasm, and abasing oneself. ${ }^{56}$ Since Findlay and Rachels think bowing requires relinquishing one's judgement, and they consider doing so unethical, they conclude that there is nothing we should bow to and nothing we should worship. They agree with Immanuel Kant who said that 'Kneeling down or groveling on the ground, even to express your reverence for heavenly things, is contrary to human dignity' (Kant (1994), 99). ${ }^{57}$

I agree with Findlay and Rachels that there are no ethical grounds for surrendering all judgement. But this is not what the ritual of bowing is. As I explained in the analysis of bowing, when one bows one becomes conscious of the limits of one's knowledge and 
power. This consciousness is not a surrender of one's judgement, but an acknowledgement of its limits. Rachels admits that bowing in the political realm signifies taking on a role with responsibilities, but he distinguishes this bowing from worship, because he thinks that bowing before God moulds us to be children who do not use their judgement. ${ }^{58}$ This is not what the Hebrew Bible teaches. Bowing before God, like bowing before a king, shapes one into a servant of God, who takes responsibility for others and participates in God's just rule. Being such a servant will not require the surrender of judgement but the exercise of wisdom.

A person does not surrender judgement in choosing to serve a king. Judging who and what should restrain us is an important use of judgement, not an abnegation of it. Judgement is used to choose which rulers and which systems of law are good and therefore should restrain our actions. In the biblical narrative we find that God expects the Israelites to exercise such judgement. For example, when God introduces himself to the Israelite nation at Sinai he introduces himself as the God who took them out of Egypt, right in the same verse where he commands that they should have no other gods (Exodus 20:2). God gives the Israelites reasons to worship him: God saved them from bondage and promised them a safe haven, while other gods did not. God thereby appeals to the judgement of the people, inviting them to use their judgement in deciding to worship God.

Notice that the discussion of grounds here is dramatically different from the one Bayne and Nagasawa were conducting, because the Hebrew Bible is not seeking to ground an attitude that is unlike any other. On the contrary, the reasons for serving God are the very same reasons for serving a human king. As Joshua Berman points out, God's introduction is similar to introductions offered by kings of the Ancient Near East in their agreements with their underlords. Kings would recount the ways in which they benefited weaker parties in order to convince them to join in an alliance. ${ }^{59}$ Similarly, when God commands us to bow before him he asks us to consider his qualities as we know them and to judge whether God is the best master for us to serve. ${ }^{60}$

Not only does worship not require surrender of judgement, it also does not require blind obedience. ${ }^{61}$ Rachels thinks that being subservient means '[t]hat God is not to be judged, challenged, defied, or disobeyed ... to do any of these things is incompatible with taking him as One to be worshipped' (Rachels (1971), 334). But this is not what we find in the Hebrew Bible's descriptions of the servant. The servant of God follows God's instructions and carries out his will, as Moses does when he goes to Egypt to free the Israelite slaves. But the servant of God also challenges God at times, as Abraham does when he demands that God judge Sodom justly (Genesis 18), and as Moses does when he demands that God not kill the Israelites after the sin of the Golden Calf (Exodus 32). A loyal servant doesn't judge or disobey God as though he were God's equal. But the loyal servant of God does challenge God to be just and fulfil his alliances.

We see then that bowing and service require judgement and do not require blind obedience. Thus Findlay and Rachels's view that bowing is demeaning can only be maintained if there is no ethical significance for service and obedience is belittling in itself. I contend that bowing as part of the service of God teaches that according to the Hebrew Bible service elevates a human being. Since human beings are limited in power and understanding, they need to be part of a social structure that gives them stability and prosperity. In actively serving the leader of a just social structure, a person takes responsibility for achieving peace and prosperity for himself and others. Thus it is not degrading to bow before great leaders who are just, and it is not degrading to serve God who is just. Rather there is both greatness in judging who the best master is and heroism in serving this master with loyalty. 


\section{The ethical significance of bowing in service of God}

I have argued that bowing is not demeaning but elevating, empowering a person to take responsibility for others by making a person aware of his need for society and guidance. In this section I argue further that the worship of bowing teaches that according to the Hebrew Bible the relationship with God is dependent on human relationships. This view of the relationship to God is preferable to a one-on-one view of the relationship with God because it indicates God's interest and concern for the political and social realm of human life. ${ }^{62}$ Thus worship as bowing shapes the servant of God to view herself a member of society and motivates her to join God's efforts in bringing about justice to her society.

In his essay 'The Problem of Total Devotion' Robert Adams suggests that there are two kinds of relationships, ${ }^{63}$ what I will call one-on-one relationships and composite relationships. A one-on-one relationship is the kind a couple might have, or a painter might have to his painting. Though such a relationship may have been brought about by a third party, the relationship is not ontologically dependent on other relationships. Composite relationships, on the other hand, supervene on other relationships. For example, a basketball player relates to a member of his team as his teammate. But there would be no team if the two players had no relation to the other teammates. The first relationship of 'teammate' that holds between two players supervenes on the relationships among all members of the team. Thus the player's relationship to one teammate is dependent on his relationships to the other team members.

Characterizations of worship as an attitude, which is internal to an individual worshipper, usually assume a one-on-one relationship between God and man. Emphasis on the appropriate reactive attitude indicates a view of the relationship as one in which God and the human being relate to each other alone. As such, these conceptions are not dependent in any way on relationships with other human beings. These conceptions of worship do not view our relationships with other human beings as intrinsically relevant to worship. Worship transcends human relationships, standing separately from them. ${ }^{64}$

Swinburne's view, discussed above, suggests such a one-on-one relationship between God and man. Swinburne's view of worship as respect characterizes worship as an attitude taken up towards God. While it compares worship to the attitude adopted in other relationships, it does not depend on the worshipper's other relationships. Acknowledging the greatness of one being does not depend on acknowledging the greatness of another. The worshipper succeeds in worshipping, if he or she has the appropriate form of respect when encountering God. If this person is disrespectful of human beings, this has no bearing on her worship of God.

The Hebrew Bible, on the other hand, teaches that our relation to God is not only modelled on human relationships, but also supervenes on our human relationships. The metaphor of God as king indicates that our relationship with God is not a one-on-one relationship but a composite relationship. ${ }^{65}$ A king's attitude towards a particular subject is dependent on that subject's relationships with the other subjects. If one of the king's subjects murders another, the king's concern for his other subjects will shape his treatment of the murderer. No matter how much the king previously loved the murderer, the king will view the murderer as harmful to the kingdom and to the king himself because he is harmful to the other subjects. Thus depicting God as king teaches that our relationships with other people shape our relationship with God. God's relationship to us as individuals does not transcend our human relationships but supervenes on them.

The composite nature of our relationship with God does not imply that our human relationships are of value only as parts of our relationship with God. The importance of human relationships is taken as a given in the Hebrew Bible; if they are the model for 
our relationship with God, they must have some worth on their own. Breaking with the rituals of other religions of the Ancient Near East, God of the Hebrew Bible forbids child sacrifice and prostitution in the Temple service. ${ }^{66}$ This is because God forbids using our intimate human relationships in order to serve him, through sacrifice of these relationships or through their ritualization. Our human relationships have worth in and of themselves.

Rather than requiring that human relationships be sacrificed to serve God, God shows an active interest in the flourishing of these relationships. There are numerous laws in the Hebrew Bible regarding the treatment of our family members, our employees, our nation, and even our enemies. God who is king demands that we conduct our human relationships with charity and justice and instructs us in how to do so. Thus the act of bowing in service of God forms and motivates us to take more interest in, and responsibility for, the wellbeing of the human beings around us.

Of course some traditions that shape a one-on-one relationship with God also teach that God commands that we treat other people well. For example, Swinburne at times implies that respect for God requires obedience, and this for him includes obeying God's commands regarding how we treat other human beings. But there are significant differences between the ethical implications of the one-on-one relationship with God and the ethical implications of the composite relationship with God.

First, on a one-on-one view of the relationship with God, other relationships are only relevant to the relationship with God insofar as God commands pertaining them. It is not the relationship with another person, but only obeying God's instructions regarding it, which is part of the relationship with God. Going beyond God's commands, and taking initiative to improve human relationships, would not be part of serving God on this view. On the composite view, on the other hand, a person who acts to bring about justice does not need to follow a command in order to be acting in service of God. Since it is the human relationships themselves that are part of a person's relationship with God, a person will be serving God whenever a person acts to improve his or her human relationships. As I argued, the service of God taken up through bowing down cannot be reduced to obedience.

Second, the composite view of the relationship with God teaches each individual who seeks God to view himself as a member of a society. This is because the composite view teaches that God does not forge relationships with individuals alone. God introduces himself to individuals as the God of their forefathers. ${ }^{67}$ Moreover, the relationship between an individual and God is shaped by the individual following God's laws, and the responsibility to follow the laws is derived from God's giving the laws to a people. ${ }^{68}$ God commands a people because God is concerned not only with the well-being of individuals, but is concerned with achieving justice for a society. This means that in order for an individual to serve God he must come to view himself as part of a society, and come to view his relationship with God as part of an alliance with this society. Such a person will value justice for his society as a goal to strive for in itself, as God does, and not only as a means to improve his personal relationship with God.

The difficulty with the composite view is that, at first glance, it does not offer the individual closeness to God. The one-on-one view offers the individual the possibility of closeness to God because it offers a relationship that is independent of other relationships. This gives a person control of his relationship with God, even when he is estranged from human beings. But although the composite view renders one's relationship with God contingent on human relationships, this contingency does not render the relationship any less close. The Hebrew Bible clearly states that individuals, such as Abraham or Moses, were particularly known to God. ${ }^{69}$ The difference is that these individuals did not achieve closeness to God by adopting a certain attitude towards God alone. They became close to 
God by sharing God's social aims and contributing to God's efforts of achieving them. They developed their loyalty to God by taking responsibility for other human beings, and became close to God by utilizing their own power and influence to improve the lives of others and by showing them God's way.

Thus we can conclude that bowing in service of God has strong ethical significance. Bowing forms a composite relationship between a person and God, which is dependent on that person's relationships with other human beings and on God's relationships with other human beings. This means that worshipping God, according to the Hebrew Bible, does not merely require caring for other humans in accordance with God's specifications. Rather worshipping God as king forms individuals who are invested in social projects larger than themselves, and who initiate taking responsibility for other human beings. These individuals know their relationship with God is not wholly their own creation but is dependent on the relationship God forges with others as well.

Finally, now that we understand the composite nature of the biblical relationship between God and man, we can better understand why worship of God does not exclude the worship of human beings. God is a jealous God, but he is not jealous of our human relationships. The commandments to worship and serve God are not commandments to serve God alone, rendering this service unique and excluding other forms of service. The commandment is rather to serve God with and through our other relationships of service. We may bow before a master or a king, so long as they in turn serve God by working towards justice and peace. ${ }^{70}$ God is one because he stands at the head of the political realm of which we are a part, and our relationship with God is unique because it is influenced by all our other relationships.

\section{Conclusion}

In this article I make a case for the epistemic and ethical virtues of biblical worship. I argued that bowing in service of God avoids the epistemological difficulties facing other accounts of worship because it is modelled on familiar human relationships. I also argued that it has ethical significance because it teaches that our relationship with God supervenes on human relationships. The Hebrew Bible's teaching that worship is bowing before God as king teaches the worshipper that God has a composite relationship with human beings, emphasizing the worth of human relationships and their political dimension. It teaches individuals to view themselves as part of a society and to come close to God by joining his efforts to bring justice and peace to society.

There is much to question regarding this form of worship. How do we know that our relationships are in the service of God? And what is the appropriate balance between humility and judgement in a loyal servant? But I want to conclude with questioning the relevance of this form of worship. The metaphor of God as king was developed at a time when human beings were ruled by kings. The prophets of Israel used this metaphor to describe God because they thought its familiarity would help their listeners serve God. Does this metaphor do the same for us today? Can we learn how to serve God by bowing down, even if we live in countries that are led by individuals who are voted in and out office?

There is much to discuss here, but I think that ultimately the answer is affirmative. This is because the value of biblical service teaches responsible loyalty to one's society. The conception of kingship taught by the Hebrew Bible was new and revolutionary in its own time. Moses taught the Israelite nation that the king of Israel must be limited in his power, ${ }^{71}$ augmenting the king's dependence on the service of his people. In this way, the Hebrew Bible taught that the well-being of nations cannot be achieved by the king alone and requires the loyal service of individuals. The value of service, in this 
respect, is no less relevant today than it was in the time of the Hebrew Bible. If biblical worship motivates us to use our judgement in choosing a political structure that we have reason to serve, and shapes us to be loyal servants of this political structure, then it is a form of worship that is as important as ever in our democratic age. ${ }^{72}$

\section{Notes}

1. My discussion of biblical worship may imply a view of God's nature that is incompatible with Classical Theism. For opposing views on the compatibility between the Hebrew Bible's view of God's nature and Classical Theism see Stump (2016); Hazony and Johnson (2018).

2. Findlay (1948); Rachels (1971); Bayne and Nagasawa (2006); Aikin (2010).

3. This argument is supported by Rabbi Levi ben Gershom (Gersonides/Ralbag, 1288-1344) who argued that we attribute to God those attributes known from our own experience: 'It is evident that we proceed to affirm attributes of God from that with which we are familiar' (Ben Gershom (1987), II, 108).

4. I thank an anonymous reviewer for suggesting this defense of Bayne and Nagasawa.

5. Mark Wynn argues that worship of God is 'engaging in an activity that finds no real parallel in our relations with created things' (Wynn (1999), 144-145). But when Wynn describes the attitude of worship he mentions attitudes of awe and wonder (ibid., 150). He says that 'in worship the believer celebrates the very existence of things' (ibid.). Once one compares this description to the attitude of a midwife watching a birth, it is not clear to me Wynn's description passes his own test.

6. Bayne and Nagasawa define worship a 'cluster concept', which is (1) non-propositional, (2) involves affects and attitudes, (3) may include an aesthetic component such as admiration. See Bayne and Nagasawa (2006), 300.

7. Gwiazda (2011); Danaher (2012). These philosophers argue about the obligation to worship (as do Bayne and Nagasawa). I do not engage with this discussion here, since I think it would require a careful study of the psychological nature and normative source of obligation and would lead this article onto another topic completely.

8. Crowe (2007), 469, 471.

9. Critics of worship accept the uniqueness thesis. See Aikin (2010), 103; Rachels (1971), 325. Findlay doesn't posit that worship must have only one object, though he thinks that worship is only appropriately directed to one who is necessarily infinitely better than all creatures. Findlay (1948), 180-181.

10. Bayne and Nagasawa (2006), 301-302. For the biblical prohibition to bow and to serve other Gods, see also Deuteronomy 11:16.

11. For the connection between the uniqueness thesis and the uniqueness of worship, see Bayne and Nagasawa (2006), 302, 306.

12. This biblical tradition was carried on into the Talmud and Midrash. I merely focus on the Hebrew Bible to make the argument more concise.

13. I acknowledge that there is a tradition, both Jewish and Christian, to read the terms describing both God and human beings equivocally. In a similar vein, one could read the commandments to bow, serve, love and fear God equivocally, and hold that they refer to sui generis attitudes when directed towards God. But the majority of Jewish tradition has not held this equivocal reading. Gersonides objects at length to Maimonides' view that attributes of God and man are used equivocally. See Ben Gershom (1987), 107-131. Even Hasdai Crescas (1340-1410) who defends Maimonides' equivocal approach seems to agree with Gersonides on the non-equivocality of religious language. See Crescas (2018), 137 and fn. 54.

14. Hazony (2012), 84-86. See also Hazony (2018), 12.

15. I refer to the King James Bible because other translations are not consistent in their usage of worship, using it to translate different verbs in the original Hebrew.

16. If we look at the historical use of 'worship', it seems that it did not always have the sui generis or unique component stipulated by recent literature. Having its source in old English, worship meant to regard something according to its worth. The verb was used for centuries to mean 'regard or habitually treat with honour or respect', and often described an attitude directed towards humans. Oxford English Dictionary, 'worship' https://www-oed-com.ezproxy3.library.arizona.edu/view/Entry/230346.

17. It is possible, as suggested by an anonymous reviewer, that there is a sui generis attitude taught and experienced in some religions but not taught or experienced by those who follow the Hebrew Bible. But this is not a defence of the uniqueness thesis as suggested by Bayne and Nagasawa, since they clearly present a view that is drawing on the Hebrew Bible and not a view that is meant to exclude the Hebrew Bible from the concept of worship.

18. Swinburne holds the view that God is the ultimate, but not the only, addressee of worship. See Swinburne (1993), 298. This view should be distinguished from the one defended by Hugh Burling. Burling, who posits that 
worship is a unique kind of respect, argues that God is the only addressee of worship because He is (contingently) the only one most excellent. Burling (2019), 490. It appears that on Burling's view, the fact that God is the most excellent would require that the attitude taken up towards him would be unique. On Swinburne's view there is no indication of this. The uniqueness of an attitude is decided by its phenomenology and not by its recipient. Thus respect towards God may limit the respect we have towards others, but it is not a different attitude.

19. Wynn objects to this view of God as the ultimate, but not the only, addressee of worship. Wynn(1999), 144145. Wynn argues that worship, in its very essence, is a response to the difference between God and man: 'the appropriateness of worship rests on some fundamental differences between human beings and God' (Wynn (1999), 151). While most theists would agree that there are differences between God and human beings, it is far from clear that these differences ground worship. It seems unlikely that the very fact that God has no body, for example, merits worship.

20. Swinburne (1993), 293.

21. Burling avoids the epistemic challenges to the sui generis worship since, according to his view, worship is like respect, so there is a human attitude we can draw on to give worship content. Burling is not very specific about the difference between respect and its unique form of worship. He says that for the well-constituted person, the phenomenological difference between respect and worship will be obvious; Burling (2019), 492. In order to give some content to worship, Burling suggests that it includes attitudes of awe or admiration (ibid., 494). If we go with Burling's suggestion of associating worship with admiration and awe, then the stipulation of uniqueness is unnecessary and unhelpful. Admiration and awe, on their own, serve as the parallels in human experience that Burling set out to find. Burling does this because he thinks respect is an obligatory attitude, while awe and admiration on their own are not, and he thinks worship must be obligatory. But it weakens his analysis of worship to stretch the meaning of respect to include so many attitudes.

22. Burling (2019), 494-495; Swinburne (1993), 293.

23. Mishnah Sanhedrin, ch. 7 Mishnah 6.

24. Swinburne (1993), 293.

25. Ibid., 294-295.

26. I follow Rachels here. He objects to defining ritual as an attitude or set of beliefs and focuses the definition of worship on ritual. See Rachels (1971), 325, 329.

27. Robert M. Adams suggests that ritual is a representation of the ideal for the relationship between God and man, which is never met in practice; Adams (1999), 225-228. This view considers worship a symbol of an ideal, and thus it also does not acknowledge ritual's active role in shaping the worshipper and the relationship.

28. Smart (1972), 26-27. Smart thinks that the sentiment of awe distinguishes worship from other acts of homage to superiors. See ibid., 21.

29. For a discussion of the Jewish rituals as forming one's character, see Berkvoits (2002), 24-27.

30. Bell (2009), 47-55.

31. Ibid., 82-83.

32. Ibid., 100; see also ibid., 82-85.

33. Rachels argues for a theory of ritual that is closest to this one, when he discusses political rituals. Unfortunately he does not extend this theory to include religious ritual. Rachels (1971), 330-331.

34. The superiority of God renders him hierarchically above the worshipper. This fits with Swinburne's view that God is worshipped as the ruler of the universe, and Burling's view that God is worshipped because he is maximally good.

35. Smart (1972), 44. Those who object to worship usually agree with this definition. See Rachels (1971), 331; Findlay (1948), 179.

36. Crowe argues for the intelligibility of various forms of worship. See Crowe (2007), 469-471.

37. In this article I focus on understanding the form of worship of bowing in service, because I think it is most fundamental to the relationship between man and God as king. I do not mean to imply that there aren't other forms of worship in the Hebrew Bible, such as prayer or sacrifice, just as there are other depictions of God as a father, a stone or a lover. There is more work to be done here, to understand how a person combines the various forms of worship and what they teach as a whole. All these forms of worship will fit the general thin concept of worship I proposed in the previous section.

38. Johnson (2016), ch. 7.

39. See Johnson's discussion of the role of body in cognition. Ibid., 99-113.

40. Ibid., 41-46.

41. This claim is different from Smart's claim that we hide our gaze because we should not casually view our superior. Smart (1972), 41.

42. I thank David Worsley for this point.

43. Rachels (1971), 329-330. 
44. Smart contends that bowing maintains the status quo in a relationship of power. Smart (1972), 16-17.

45. Rachels (1971), 331.

46. This broad spectrum of eved is retained throughout the Hebrew Bible. A person who loses all their possessions and is sold into service of another is called an eved (Deuteronomy 15:12). But not all avadim are slaves. Anyone who has a master above him is called an eved. Abraham's second-in-command is an eved (Genesis 24:2), and David's war heroes are his avadim (Samuel 1 25:10). See Jenni and Westermann (1997), 821.

47. You can see that the Hebrew Bible teaches that having no king makes for chaos and bloodshed in the stories of the Book of Judges and the repeated injunction 'In those days there was no king in Israel, each man did as was right in his own eyes' (for example Judges 21:25).

48. The individuals God refers to as eved hashem take actions which carry out God's goals: Abraham sets out to found a people who will be just and righteous; David establishes the Israelite Kingdom; Nebuchadnezzar destroys the corrupt kingdom; etc. The list of the servants of God goes on: Abraham in Genesis 26:24; Moses in Numbers 12:7; Caleb in Numbers 14:24; Joshua in Joshua 24:29; David in Samuel II 3:18; Nebuchadnezzar in Jeremiah 25:9; and others.

49. See the individuals who are called eved: Abraham is a wealthy patriarch who wins wars and is a sought-after ally; Moses stands up against Pharaoh and is a powerful orator and legislator; Nebuchadnezzar is an emperor, one of the most powerful individuals in the ancient world.

50. There is no word for 'obey' in Biblical Hebrew, only 'listen to the voice' (lishmo'a bekol).

51. As is shown in the biblical story of Nadav and Avihu (Leviticus 10), the ritual priests must carry out the rituals with precision, lest they jeopardize the relationship between God and the people.

52. See for instance Samuel I 15:22; Isaiah 1. See also Samuel chastising Saul for precisely this mistake: 'Does God prefer sacrifices to your listening to his voice?' (Samuel I 15:22).

53. See Kleinig (2015), 15-18, 124.

54. Joshua Berman argues that concepts such as love, which are today considered emotions, were also concepts referring to actions in the Hebrew of the Bible. Berman (2008), 34.

55. God himself has emotions like mercy, jealousy, and love, but he is primarily the God who redeems and does justice. This is why God introduces himself at Sinai as the God who took the Hebrews out of Egypt (Exodus 20:2). 56. Findlay (1948), 177.

57. The rabbis often criticize individuals in the Hebrew Bible for bowing down. See for instance the criticism of Jacob for bowing before Esau, in Genesis Rabbah 78:8. In line with my own view of bowing, I would argue that the criticism is that Jacob bowed before one who is not a just and charitable master.

58. Rachels (1971), 331.

59. Berman (2008), 28-44.

60. The judgement here is not that God is maximally good, which may not be possible for humans to judge. Rather it is the judgement that God is a good master for us. This may escape Hazony's criticism of judging God's worth. See Hazony (2018), 22.

61. Kleinig argues that loyalty does not require suspension of judgment and at times requires being critical of the object of loyalty. See Kleinig (2015), 76-79, 108-127, 162-164.

62. Notice that the political in the Hebrew Bible is always closely tied with the ethical and is shaped by it. For a discussion of this see Unterman (2017), ch. 2.

63. Adams (1993), 113-114.

64. Adams grapples with this question. Adams (1993), 109.

65. The same can be said for the biblical metaphor of a child and father - this is an incredibly personal relationship. And yet if there are other children in the picture, this relationship will be part of the composite familial relationship. This metaphor, too, indicates a relationship that is not one-on-one but composite. One might think that the lover metaphor would be different, and that God chooses the lover metaphor to indicate that he does have a one-on-one relationship with each individual, which is not comprised of his relationships with other people. But this is in fact a misreading of the Hebrew Bible's metaphor. As Berman points out, God is only depicted as the lover of the People of Israel as a collective. Berman (2008), 44-46. Thus the metaphor of lover also refers to a composite relationship.

66. See the prohibitions in Leviticus 18:21, Deuteronomy 23:19. For a discussion of prostitution in temples in the Ancient world, see Silver (2006).

67. See Genesis 28:13; Exodus 3:6 and the opening of the silent prayer said by Jews for thousands of years.

68. For a related discussion of the difference between individual knowledge of God and communal knowledge of God, see Cockayne (2019).

69. Genesis 18:18; Exodus 33:17.

70. For lack of space, I do not address the view, proposed by both Gideon and Samuel, that there should be no king in Israel because God alone is king. This view is given a prominent place in the biblical narrative. I do not 
address it because ultimately it seems that God does not disapprove of kingship, as long as the king serves God. In Deuteronomy Moses instructs the people to anoint a king (Deuteronomy 17:16), and God himself intervenes to tell Samuel to anoint a king (Samuel I 8:9).

71. Berman (2008), ch. 2.

72. The author wishes to thank the John Templeton Foundation for the grant awarded to write the first version of this article for the conference 'Worship: A Jewish Philosophical Investigation'. The author is indebted to the following for their comments on earlier drafts: Robert M. Adams, Julia Annas, Yoram Hazony, Dru Johnson, Sam Lebens, Eliyahu Levi, Eleonore Stump, David Worsley, and an anonymous reviewer.

\section{References}

Adams RM (1993) The problem of total devotion. In Badhwar NK (ed.), Friendship: A Philosophical Reader. Ithaca, NY: Cornell University Press, pp. 108-132.

Adams RM (1999) Finite and Infinite Goods: A Framework for Ethics. Oxford: Oxford University Press.

Aikin SF (2010) The problem of worship. Think 9, 101-113.

Bayne T and Nagasawa, Y (2006) The grounds of worship. Religious Studies 42, 299-313.

Bell C (2009) Ritual Theory, Ritual Practice. New York, NY: Oxford University Press.

Ben Gershom L (Gersonides) (1987) The Wars of the Lord. S. Feldman (trans.). 3 vols. Philadelphia, PA: The Jewish Publication Society.

Berkovits E (2002) Law and morality in the Jewish tradition. In Hazony D (ed.), Essential Essays on Judaism. Jerusalem: Shalem Press, pp. 3-40.

Berman J (2008) Created Equal: How the Bible Broke with Ancient Political Thought. Oxford: Oxford University Press. Burling H (2019) Do we owe God worship? Religious Studies 55, 487-502.

Cockayne J (2019) Common ritual knowledge. Faith and Philosophy 36, 33-55.

Crescas H (2018) Light of the Lord. R. Weiss (trans.). Oxford: Oxford University Press.

Crowe BD (2007) Reasons for worship: a response to Bayne and Nagasawa. Religious Studies 43, 465-474.

Danaher J (2012) Stumbling on the threshold: a reply to Gwiazda on threshold obligations. Religious Studies 48, 469-478.

Findlay JN (1948) Can God's existence be disproved?. Mind 57, 176-183.

Gwiazda J (2011) Worship and threshold obligations. Religious Studies 47, 521-525.

Hazony Y (2012) The Philosophy of Hebrew Scripture. Cambridge: Cambridge University Press.

Hazony Y (2018) Is God 'perfect being'? In Hazony Y and Johnson D (eds), The Question of God's Perfection. Leiden and Boston, MA: Brill, pp. 9-26.

Hazony Y and Johnson D (eds) (2018) The Question of God's Perfection. Leiden/Boston: Brill.

Jenni E and Westermann C (1997) Iבד'. In Biddle ME (trans.), Theological Lexicon of the Old Testament. Peabody, MA: Hendrickson Publishers, pp. 819-832.

Johnson D (2016) Knowledge by Ritual: A Biblical Prolegomenon to Sacramental Theology. Winona Lake, IN: Eisenbrauns. Kant I (1994) Metaphysical principles of virtue. In Ellington J (trans.), Ethical Philosophy. Indianapolis, IN: Hackett. Kleinig J (2015) On Loyalty and Loyalties: The Contours of a Problematic Virtue. New York, NY: Oxford University Press. Rachels J (1971) God and human attitudes. Religious Studies 7, 325-337.

Silver M (2006) Temple/sacred prostitution in Ancient Mesopotamia revisited: religion in the economy. Ugarit-Forschungen 38, 631-663.

Smart N (1972) The Concept of Worship. London: Macmillan.

Stump E (2016) The God of the Philosophers and the God of the Bible. Milwaukee, WI: Marquette University Press. Swinburne R (1993) The Coherence of Theism. Oxford: Clarendon Press.

Unterman J (2017) Justice for All: How the Jewish Bible Revolutionized Ethics. Lincoln, NE: University of Nebraska Press. Wynn M (1999) God and Goodness: A Natural Theological Perspective. London and New York: Routledge.

Cite this article: Levi AH (2022). Worship: bowing down in the service of God. Religious Studies 58, 487-504. https://doi.org/10.1017/S0034412521000044 